DOI https://doi.org/10.30525/978-9934-26-182-4-29

\title{
СУЧАСНІ ЗАСОБИ АНАЛІЗУ ТА КОНТРОЛЮ ЯКОСТІ ЛІКАРСЬКОЇ РОСЛИННОЇ СИРОВИНИ
}

\author{
Делян Є. П. \\ кандидат фармачевтичних наук, \\ доиент кафедри терапї, фармакології, клінічної діагностики та хімії \\ Сумський національний аграрний університет \\ Улько Л. Г. \\ доктор ветеринарних наук, професор, \\ завідувачка кафедри терапї, фармакології, \\ клінічної діагностики та хімії \\ Сумський національний аграрний університет \\ Нечипоренко О. Л. \\ доктор ветеринарних наук, \\ професор кафедри терапії, фармакологіï, \\ клінічної діагностики та хімії \\ Сумський національний аграрний університет \\ м. Суми, Украӥна
}

Сучасні препарати повинні відповідати високим вимогам якості як до своєї ефективності так і до своєї безпечності. Даний постулат повністю був підтриманий ВООЗ та відображений у вигляді положень про «Залишкові кількості деяких ветеринарних препаратів в їжі» на засіданні Об'єднаного комітету ФАО/ВООЗ (Food and Agriculture Organization/ World Health Organization) по харчовим добавкам в серії технічних доповідей ВООЗ № 815, Женева 1995p [1]. В той же час вказані нововведення були інтегровані в українське законодавство зокрема в Закон України «Про ветеринарну медицину» [2], закон України «Про державний контроль за дотриманням законодавства про харчові продукти, корми, побічні продукти тваринного походження, ветеринарну медицину та благополуччя тварин» [3] та низку правил регулюючих виробництво та контроль ветеринарних препаратів GLP, GMP, GCP [4].

Отже - підходи до розробки та виробництва ВП (ветеринарні препарати) інтегровані в класичну фармацію лікарських засобів та мають відповідати найвищим стандартам якості доступним на час розробки ВП. 
Такий комплексний підхід забезпечує отримання екологічно чистої продукції тваринництва [5, с. 2] .

Інструментальні методи аналізу мають багато переваг: інформативність, можливість аналізу багатокомпонентних сумішей, висока чутливість та специфічність, автоматизація аналітичного процесу. Одним з найпростіших фізико-хімічних методів аналізу є (тонкошарова хроматографія) ТШХ. В якості експрес-методу має переваги перед іншими методами: просте апаратне забезпечення, низька мінімальна кількість субстанції для аналізу $-10^{-6}$ г, можливість отримання індивідуального компоненту суміші для подальшого аналізу. Метод ТШХ грунтується на розділенні сумішей речовин за рахунок сорбції у шарі сорбенту нанесеного на відповідну підкладку. За методом ТШХ можливо аналізувати як індивідуальні лікарські засоби [6, с. 159] так і складні багатокомпонентні суміші - екстракти лікарських рослин [7, с. 8], які містять в мажоритарних кількостях близько 100 сполук. В той же час даний метод був автоматизований та покладений в основу хроматографічного комплексу для тонкошарової хроматографії, типу HPTLC (High-performance thin-layer chromatography).

Метод HPTLC значно розширює можливості методу ТШХ та дозволяє використовувати ефективніші сорбенти, мінімізувати кількість зразку, підвищити селективність, аналізувати багатокомпонентні суміші лікарських засобів та субстанцій $[8$, с. 4].

Також велике розповсюдження отримав один 3 оптичних методів аналізу - спектрофотометрія (СФ). В залежності від діапазону хвилі розрізняють Ультрафіолетову 190 - 400 нм (УФ), Інфрачервону 760-100000 нм (ІЧ) спектрофотометрію та видиму СФ 400 - 760 нм. Одна 3 переваг методу УФ - можливість отримати сумарні значення вмісту спорідненої групи сполук. Перевагою методу ІЧ $є$ можливість ідентифікувати індивідуальну сполуку за бібліотекою спектрів, оскільки ІЧ-спектри індивідуальні для кожної речовини. Також метод ІЧ потребує мінімальну кількість зразку та $\epsilon$ можливість використовувати досліджуваний зразок в твердому вигляді.

Однак у випадку складних багатокомпонентних сумішей лікарських засобів і особливо рослинного походження (які містять велику кількість різнорідних сполук у мінорних кількостях) метод СФ має недолік: фактично неможливо ідентифікувати та кількісно визначити сполуки у сумішах які складаються 3 різнорідних груп сполук. Для аналізу багатокомпонентних сумішей лікарських засобів доцільно використовувати хроматографічні методи: високоефективну рідинну хроматографію (ВЕРХ), газову хроматографію (ГХ), високоефективну 
рідинну хроматографію $з$ мас-детекцією (BЕРХ-МС), газову хроматографію з мас-детекцією (ГХ-МС). Основою методу високоефективної хроматографії є розділення сполук між двома фазами - рідкою рухомою (або газоподібною в ГХ) та нерухомою, 3 подальшою детекцією в потоці рідини або газу кожної окремої сполуки. Метод ВЕРХ дає можливість ідентифікувати та одночасно кількісно визначити безліч сполук 3 різнорідних груп [9, с. 6] природного або штучного походження [10, с. 4]. Так в роботі по визначенню хімічного складу сухого екстракту пагонів чорниці $[11$, с.8; 12, с.4] ідентифіковано та кількісно визначено ряд сполук - хлорогенову, кофейну, ферулову, транс-п-кумарову і 3гідроксикоричну кислоту.

\section{Література:}

1. Об'єднаний комітет експертів ФАО/ВООЗ по харчовим добавкам: тридцять восьма доповідь. Серія технічних доповідей ВООЗ, № 815. Женева, 1995.

2. Закон України «Про ветеринарну медицину» 1206-IX від 04.02.2021. https://zakon.rada.gov.ua/laws/show/1206-20\#Text

3. Закон України «Про державний контроль за дотриманням законодавства про харчові продукти, корми, побічні продукти тваринного походження, ветеринарну медицину та благополуччя тварин» // Відомості Верховної Ради України. -2017. - № 31, ст. 343.

4. Клінічні дослідження ветеринарних препаратів та кормових добавок. -Львів. 2013. 252 С.

5. Полова Ж. М. Теоретичне та експериментальне обгрунтування складу та технології лікарських препаратів антимікробної дії для застосування у ветеринарії: автореф. дис. на здобуття ступеня д-ра. фарм. наук, спец. 15.00.01 технол. ліків, організ. фарм. справи та судова фарм. Харків. 2019. 46 с.

6. Павленко А.О. Визначення деяких селективних антагоністів цог-2 у біологічних рідинах. Сучасні аспекти медицини та фармації. 2015. C. 159

7. Зарівна Н. О., Логойда Л. С. Розробка методики ідентифікації флавоноїдів та гідроксикоричних кислот в екстрактах чебрецю повзучого Медична та клінічна хімія. 2020. Т. 22. № 1

8. High-performance thin layer chromatography: A powerful analytical technique in pharmaceutical drug discovery / Mahesh Attimarad, K. K. Mueen Ahmed, Bandar E. Aldhubaib, and Sree Harsha. Pharm Methods. 2011. Apr-Jun; 2(2): 71-75. 
9. Делян С.П. Дослідження вмісту флавоноїдів в листі осоту жовтого.Сучасні аспекти медицини та фармації. 2014. С. 168-169.

10. Мелікян С.М. Розробка методики кількісного визначення енрофлоксацину та ципрофлоксацину у сироватці крові курчат із використанням високоефективної рідинної хроматографії з флуорометричним детектуванням. Науково-технічний бюлетень Державного науководослідного контрольного інституту ветеринарних препаратів та кормових добавок і Інституту біології тварин. 2020. 21(2). С. 110-117.

11. Тихонов О.І., Ковальова О.О., Руденко М.В. Використання методу високоефективної рідинної хроматографії для кількісного визначення ципрофлоксацину гідрохлориду у ветеринарному препараті. Фармацевтичний журнал. 2009. № 1. С. 76-80

12. Вронська Л.В. Хроматографічний профіль гідроксикоричних кислот сухого екстракту пагонів чорниці. Фармацевтичний часопис. 2019. № 4. C. 5-14.

DOI https://doi.org/10.30525/978-9934-26-182-4-30

\title{
CONCEPT OF DRUG PSYCHOLOGY AS A NEW DIRECTION OF CLINICAL PHARMACY
}

\author{
Zimenkovsky A. B. \\ Doctor of Medical Sciences, Professor, \\ Head of the Department of Health Care Management, \\ Pharmacotherapy and Clinical Pharmacy \\ Danylo Halytsky Lviv National Medical University
}

Sekh M. Ya.

Candidate of Pharmaceutical Sciences, Assistant professor at the Department of Health Care Management, Pharmacotherapy and Clinical Pharmacy Danylo Halytsky Lviv National Medical University Lviv, Ukraine

The recent advances in medicine in general and pharmacology in particular have led to a completely new paradigm of treatment [1]. The goal of the "new age" pharmacotherapy is to transform the modern patient from a passive drug recipient to a conscious active participant with a key role in their own treatment 112 